\title{
THE GROWTH RATE OF RUFFE, GYMNOCEPHALUS CERNUUS (L., 1758) IN THE SZCZECIN LAGOON, THE ODRA MOUTH AND LAKE DABHE
}

\section{WZROST JAZGARZA GYMNOCEPHALUS CERNUUS \\ (L., 1758) W ZALEWIE SZCZECINSKIM, ROZTOCE ODRZAŃSKIEJ I JEZIORZE DARIE}

\author{
Academy of Agriculture
}

\begin{abstract}
The otoliths back readings method was applied to test the growth rate of Gymnocephalus cernuus from the three water basins of the Odra estuary area. Usability of the von Bertalanffy's equation and quadra tic and cubic polynomials theoretical reading of length and weight growth rate was compared. The weight growth of fish aged two to eight was stated to be very uniform.
\end{abstract}

\section{INTRODUCTION}

Ruffe, the most widespread species among the four ones of the Gymnocephalus genus, inhabits mostly slow lowland rivers between the north-eastern France and England and Kolyma in eastern Siberia (Collette and Banarescu, 1977). Common in Poland and present in stagnant and floating waters of all kinds, the Baltic sea-side lagoons including, omits sea waters, though (Gąsowska, 1962). In some water basins, the Szczecin Lagoon including (Peczalska, 1971) ruffe belongs to the most numerous species, however its economic value, as a nonconsumable fish, is ussually low. In the Soviet Union and the German Democratic Republic ruffe happens to be exploited 
intensively, although mostly for feed production purposes (Kozlova, 1979; Fedorova and Vetkasov, 1974; Bast et al., 1983).

Lacking in economic value, ruffe is being rather seldom an object for biological surveys in Poland. Because of that there is only some works done in this subject (in between: Zawisza, 1953; Leszczyński, 1963; Adamus et al., 1978; Terlecki, 1983). Except for Pęczalska's article (1971), dealing partly with age, growth rate and maturity problems, there have not been, also, any publication on ruffe's biology in the Szczecin Lagoon and surrounding waters.

The aim of this work was to study the growth rate of ruffe of the Szczecin Lagoon, the Odra mouth and Lake Dąbie origin and to compare it to the growth rate of the same species from other water basins.

\section{MATERIAL AND METHODS}

Fish to be studied originated from commercial catches, carried out in the Szczecin Lagoon, the Odra mouth and Lake Dąbie in 1985 and 1986 by the trap gear. Totally 183 individuals from the Szczecin Lagoon, 114 ones from the Odra mouth and 200 individuals from Lake Dąbie were collected.

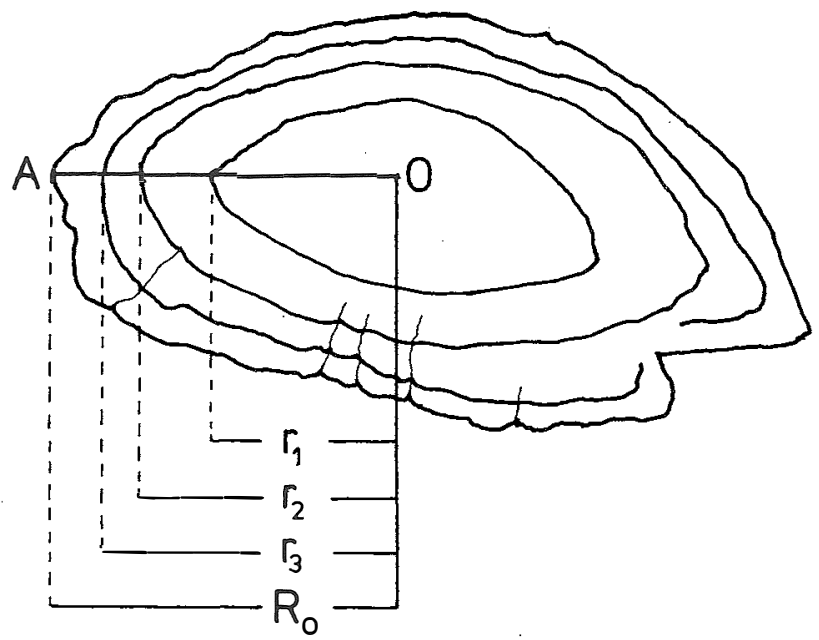

Fig. 1. A diagram of the ruffe's otoliths measurement, $O A-$ measurement zone.

The detailed characteristic of collected material gives Table 1 . All the fishes were measured (1. t. and l. c.) and their weight determined with, respectively, 0.1 $\mathrm{cm}$ and $0.5 \mathrm{~g}$ accuracy, with sex of the fish stated as well. Fish with gonads at the first maturity stage, according to the Maier's scale, was determine as "immature" with no further sex determination. The ruffe's age was determined 
from otoliths, with the growth rate being estimated by a back calculations method; relationship between the shorter otolith radius $\left(R_{o}\right)$ (Fig. 1$)$ and the body length (1. c.) marked out. That relation happened to approach a rectilinear one (Fig. 2). Regression line, expressing the above relationship, crosses the

Table 1

Tabulation of collected material

\begin{tabular}{lccccc}
\hline $\begin{array}{l}\text { Water } \\
\text { basin }\end{array}$ & Date & $\begin{array}{c}\text { Number } \\
\text { of fish }\end{array}$ & $\begin{array}{c}\text { Body length } \\
\text { average (1. c.) } \\
\text { cm }\end{array}$ & $\begin{array}{c}\text { Range of body } \\
\text { length (l. c.) } \\
\text { cm }\end{array}$ & $\begin{array}{c}\text { Range of body } \\
\text { weight } \\
\text { g }\end{array}$ \\
\hline Szczecin & 1.04 .1985 & 15 & 14.30 & $12.8-16.4$ & $50.0-110.5$ \\
Lagoon & 10.04 .1985 & 27 & 13.10 & $10.3-15.2$ & $24.0-89,5$ \\
& 20.05 .1985 & 15 & 11.54 & $7.1-16.0$ & $7.0-93.0$ \\
& 12.07 .1985 & 25 & 13.18 & $8.9-15.5$ & $15.5-90.0$ \\
& 23.08 .1985 & 25 & 9.24 & $5.5-13.3$ & $4.0-58.0$ \\
& 12.05 .1986 & 19 & 10.36 & $8.3-12.5$ & $12.0-41.0$ \\
& 26.05 .1986 & 24 & 8.49 & $4.8-13.6$ & $2.0-58.0$ \\
\hline Odra & 16.06 .1986 & 33 & 9.97 & $5.4-14.5$ & $4.0-67.0$ \\
mouth & 19.08 .1985 & 51 & 11.57 & $4.7-16.1$ & $3.0-97,5$ \\
& 30.10 .1985 & 25 & 8.28 & $5.9-13.1$ & $4.5-55.0$ \\
\hline Lake & 30.07 .1986 & 38 & 9.49 & $6.0-14.7$ & $5.0-61.0$ \\
Dabbie & 29.04 .1985 & 27 & 11.19 & $7.5-15.3$ & $7.5-79.0$ \\
& 6.05 .1985 & 24 & 12.08 & $8.8-15.2$ & $14.0-83.0$ \\
& 19.06 .1985 & 11 & 9.08 & $7.5-10.3$ & $10.5-26.0$ \\
& 30.08 .1985 & 4 & 9.83 & $8.0-11.3$ & $13.5-26.0$ \\
& 10.09 .1985 & 16 & 10.84 & $8.4-13.2$ & $12.5-48.5$ \\
& 18.09 .1985 & 14 & 8.09 & $5.5-15.0$ & $3.0-69.0$ \\
& 7.05 .1986 & 16 & 11.18 & $8.5-13.4$ & $14.0-48.0$ \\
& 9.05 .1986 & 46 & 11.04 & $7.8-14.7$ & $10.0-64.0$ \\
& 5.06 .1986 & 13 & 10.38 & $7.1-13.1$ & $6.0-44.5$ \\
& 5.09 .1986 & 29 & 8.15 & $6.4-11.4$ & $6.0-25.0$ \\
\hline
\end{tabular}

$X$-axis at $0.08 \mathrm{~cm}$ distance from the origin of coordinates. Due to such a small displacement, the back calculations of growth were done according to the Dahl-Lea method, with no correction being introduced.

Theoretical length growth rate of the ruffe, was determined by the two methods:

a) by von Bertalanffy's equation:

$$
L_{t}=L_{\infty}\left[1-e^{-K\left(t-t_{0}\right)}\right]
$$

where: $t=$ fish age

$L_{t}=$ fish length at the age $t$

$L_{\infty}=$ asymptotic length

$K=$ coefficient of catabolism

$t_{o}=$ age of the theoretical beginning of the fish growth 
b) by quadratic polynomials:

$$
L_{t}=a+b t+c t^{2}
$$

where: $L_{t}$ and $t=$ the same as in formula (1)

$a, b, c=$ parameters, determined by the least square method.

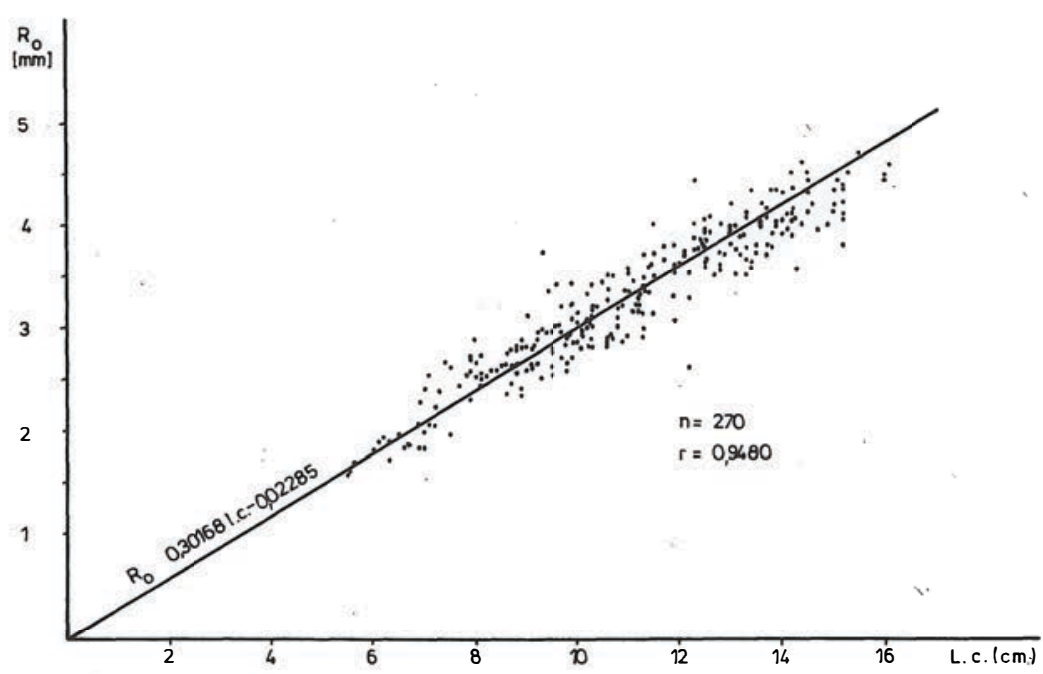

Fig. 2. Relationship between body length (1. c.) and a shorter otolith radius of ruffe $\left(R_{o}\right)$.

Due to the formula given by Szypula (1977) $t_{\max }$ (theoretical maximum age of fish) and $L_{\max }$ (theoretical maximum length of fish) were estimated.

Relationship between the body length and body weight of fish was determined according to the formula:

$$
W=k L^{n}
$$

where: $W=$ total body weight $(\mathrm{g})$

$$
L=\text { body length (1. c.) }(\mathrm{cm})
$$

$k, n=$ coefficients determined by the least square method.

A theoretical body weight growth rate of the ruffe was presented by: a) modified von Bertalanffy's equation:

$$
W_{t}=W_{\infty}\left[1-e^{-K\left(t-t_{0}\right)}\right]^{n}
$$

where: $W_{t}=$ fish weight at the age $t$

$W_{\infty}=$ asymptotic weight

$n=$ exponent from the formula (3), defining relationship between the length and body weight

$K, t, t_{o}=$ designations as in formula (1) 
b) a cubic polynomial:

$$
W_{t}=a+b t+c t^{2}+d t^{3}
$$

where: $W_{t}=$ fish weight at the age $t$

$a, b, c, d,=$ parameters determined by the least square method.

\section{RESULTS}

Relationship between the total body length and body length of ruffe.

To compare results obtained by various authors, whenever needed, a total body length (1.t.) was counted over to a body length (1.c.) by applying a relationship 1. c. $=0.85961$. t. -0.3904 , based on measures of 496 ruffes from the three analyzed water basins.

\section{Length growth rate}

Table 2 and Figure 3 present data illustrating the body length growth rate of ruffe from the three studied water basins, while Tables 3,4 and 5 include annual increments in succesive calendar years. Up to the seven years of growth,

Table 2

The growth rate of ruffe in the studied water basins $1 . c .(\mathrm{cm})$

\begin{tabular}{|c|c|c|c|c|c|c|c|c|c|c|}
\hline \multirow{2}{*}{$\begin{array}{l}\text { Water } \\
\text { basin }\end{array}$} & & \multicolumn{9}{|c|}{ Age of fish } \\
\hline & & 1 & 2 & 3 & 4 & 5 & 6 & 7 & 8 & 9 \\
\hline $\begin{array}{l}\text { Szczecin } \\
\text { Lagoon }\end{array}$ & $\begin{array}{c}\bar{x} \\
\pm s \\
n \\
\text { increment l.c. } \\
\bar{x} \text { \&ᄋ } \\
n \\
\bar{x} \sigma_{n}^{\bar{\alpha}} \\
n\end{array}$ & $\begin{array}{c}0.63 \\
171 \\
5.82 \\
5.80 \\
111 \\
5.90 \\
49\end{array}$ & $\begin{array}{c}8.63 \\
0.96 \\
138 \\
2.81 \\
8.63 \\
94 \\
8.67 \\
43\end{array}$ & $\begin{array}{c}10.11 \\
1.05 \\
101 \\
1.48 \\
10.10 \\
73 \\
10.13 \\
28\end{array}$ & $\begin{array}{c}11.36 \\
1.14 \\
86 \\
1.25 \\
11.35 \\
67 \\
11.38 \\
19\end{array}$ & $\begin{array}{c}12.32 \\
1.07 \\
60 \\
0.96 \\
12.32 \\
53 \\
12.33 \\
7\end{array}$ & $\begin{array}{c}13.14 \\
0.90 \\
42 \\
0.82 \\
13.13 \\
38 \\
13.22 \\
4\end{array}$ & $\begin{array}{c}13.49 \\
0.88 \\
19 \\
0.35 \\
13.52 \\
16 \\
13.31 \\
3\end{array}$ & $\begin{array}{c}14.08 \\
1.15 \\
7 \\
0.59 \\
14.24 \\
6 \\
13.11 \\
1\end{array}$ & $\begin{array}{c}14.13 \\
- \\
3 \\
0.05 \\
14.40 \\
2 \\
13.60 \\
1\end{array}$ \\
\hline $\begin{array}{l}\text { Odra } \\
\text { mouth }\end{array}$ & 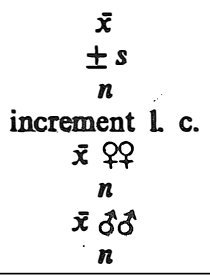 & $\begin{array}{c}5.96 \\
0.66 \\
103 \\
5.96 \\
5.97 \\
76 \\
5.86 \\
21\end{array}$ & $\begin{array}{c}8.25 \\
0.81 \\
74 \\
2.29 \\
8.30 \\
58 \\
8.12 \\
13\end{array}$ & $\begin{array}{c}9.79 \\
0.77 \\
47 \\
1.54 \\
9.79 \\
39 \\
9.76 \\
8\end{array}$ & $\begin{array}{c}10.70 \\
0.88 \\
37 \\
0.91 \\
10.71 \\
32 \\
10.60 \\
5\end{array}$ & $\begin{array}{c}11.87 \\
0.70 \\
29 \\
1.17 \\
11.91 \\
27 \\
11.39 \\
2\end{array}$ & $\begin{array}{c}12.78 \\
0.70 \\
22 \\
0.91 \\
12.85 \\
20 \\
12.05 \\
2\end{array}$ & $\begin{array}{c}13.70 \\
0.92 \\
8 \\
0.92 \\
13.70 \\
8 \\
- \\
-\end{array}$ & $\begin{array}{c}14.71 \\
- \\
4 \\
1.01 \\
14.71 \\
4 \\
- \\
- \\
\end{array}$ & $\begin{array}{c}14.95 \\
- \\
2 \\
0.24 \\
14.95 \\
2 \\
- \\
-\end{array}$ \\
\hline Lake Dąbie & 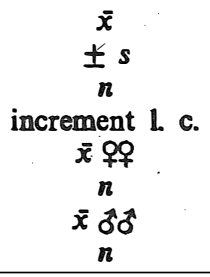 & $\begin{array}{l}5.79 \\
0.67 \\
195 \\
5.79 \\
5.84 \\
134 \\
5.68 \\
61\end{array}$ & $\begin{array}{c}8.34 \\
1.16 \\
171 \\
2.55 \\
8.43 \\
120 \\
8.12 \\
51\end{array}$ & $\begin{array}{c}9.89 \\
1.17 \\
120 \\
1.55 \\
10.07 \\
86 \\
9.41 \\
34\end{array}$ & $\begin{array}{c}11.09 \\
1.18 \\
80 \\
1.20 \\
11.28 \\
58 \\
10.61 \\
22\end{array}$ & $\begin{array}{c}11.76 \\
1.07 \\
41 \\
0.67 \\
11.90 \\
32 \\
11.24 \\
9\end{array}$ & $\begin{array}{c}12.77 \\
0.96 \\
25 \\
1.01 \\
13.03 \\
19 \\
11.94 \\
6\end{array}$ & $\begin{array}{c}13.61 \\
0.92 \\
12 \\
0.84 \\
14.08 \\
8 \\
12.68 \\
4\end{array}$ & $\begin{array}{c}14.55 \\
- \\
4 \\
0.94 \\
14.55 \\
4 \\
- \\
-\end{array}$ & $\begin{array}{l}- \\
- \\
- \\
- \\
- \\
- \\
-\end{array}$ \\
\hline
\end{tabular}


increase in body length of examined ruffe from Lake Dąbie and the Odra mouth was almost identical (the growth curves at Fig. 3 almost coincide) with a slightly faster growth of that species noted for the Szczecin Lagoon. Higher differentiation in the average body length for fish aged 8 and 9 resulted,

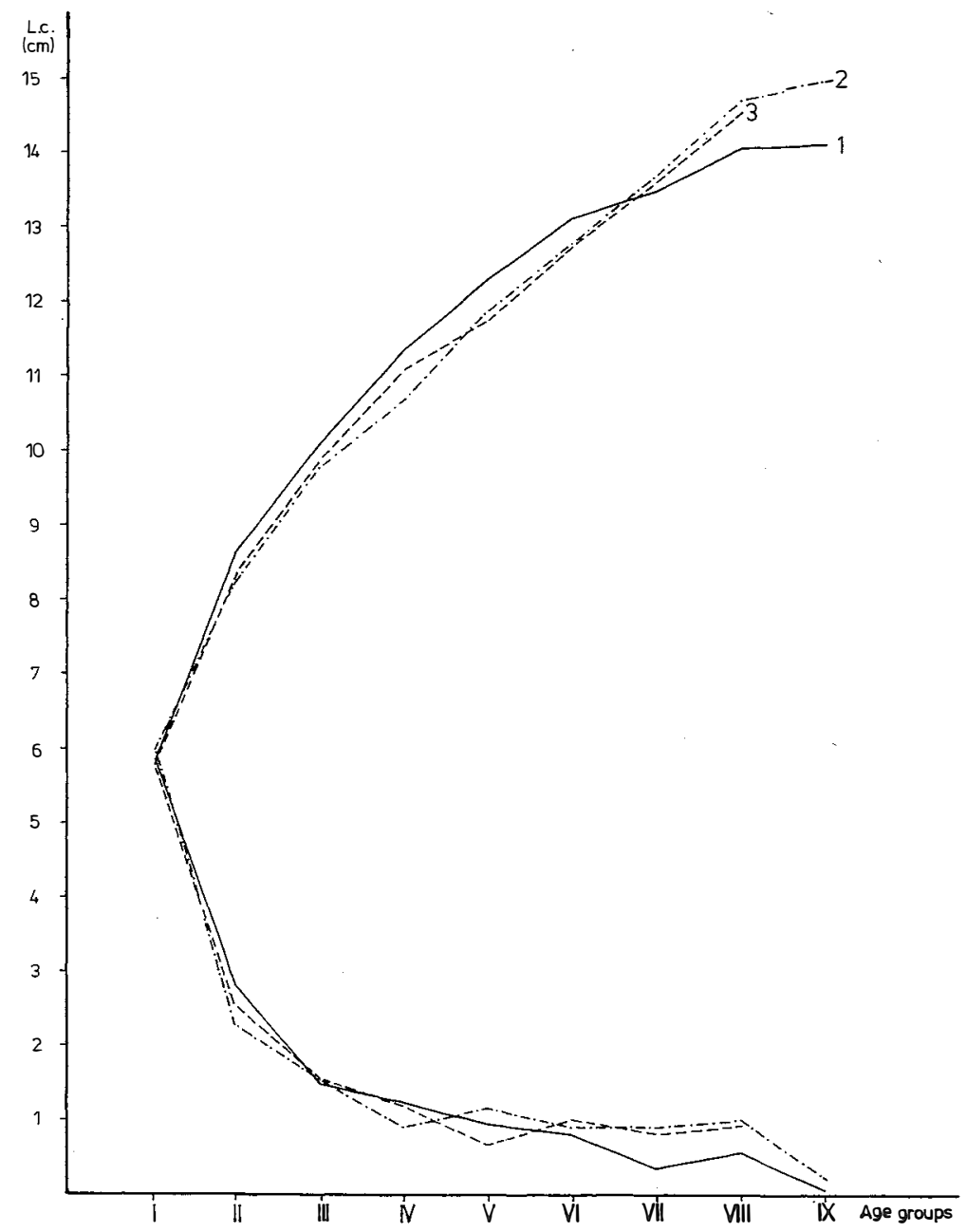

Fig. 3.Body length growth rate and average annual length increments of ruffe in the studied water basins. 1 - the Szczecin Lagoon; 2 - the Odra mouth; 3 - Lake Dąbie

rather, from less numerous material (Table 2) for these age groups, than from changes in growth character. The fastest growth of the ruffe was noted in the first year of life $(5.8 \mathrm{~cm}$ for Lake Dąbie and the Szczecin Lagoon and $6.0 \mathrm{~cm}$ for the Odra mouth). In the succesive years the length growth rates rapidly decreased - to about $2.5 \mathrm{~cm}$ in the second year, to $1.5 \mathrm{~cm}$ in the third one, 
oscilating, next, around $1 \mathrm{~cm}$, with a slightly dropping tendency (Table 2, Fig. 3). For the oldest; 9 years old fish, the body length reached up, 13.6 to $15.4 \mathrm{~cm}$ (that is 17.0 to $18.5 \mathrm{~cm} 1$. t.).

Table 3

The annual length increments of ruffe in the Szczecin Lagoon, in succesive calendar years 1.c. (cm)

\begin{tabular}{ccccccccccc}
\hline $\begin{array}{c}\text { Year } \\
\text { of growth }\end{array}$ & $l_{1}$ & $l_{2}-l_{1}$ & $l_{3}-l_{2}$ & $l_{4}-l_{3}$ & $l_{5}-l_{4}$ & $l_{6}-l_{5}$ & $l_{7}-l_{6}$ & $l_{8}-l_{7}$ & $l_{9}-l_{8}$ \\
\hline 1984 & 6.06 & 2.62 & 1.30 & 1.59 & 0.97 & 0.79 & 0.81 & 0.61 & 0.60 \\
\hline 1983 & 6.09 & 3.09 & 1.85 & 1.30 & 1.27 & 0.94 & 0.69 & 0.88 & \\
\hline 1982 & 5.92 & 2.72 & 1.70 & 1.22 & 0.91 & 0.87 & 0.89 & & \\
\hline 1981 & 5.64 & 2.78 & 1.56 & 1.04 & 0.91 & 0.98 & & & \\
\hline 1980 & 5.58 & 2.93 & 1.39 & 1.35 & 0.83 & & & \\
\hline 1979 & 5.78 & 2.77 & 1.54 & 1.60 & & & & \\
\hline 1978 & 5.55 & 3.49 & 1.68 & & & & & & \\
\hline 1977 & 5.22 & 1.64 & & & & & & & \\
\hline 1976 & 5.30 & & & & & & & & \\
\hline
\end{tabular}

According to the data in Table 3, the ruffe from the Szczecin Lagoon had better length growth rate in 1983 , than in the other experimental years, while the length growth rate of the ruffe from the Odra mouth and Lake Dąbie (Table 4 and 5) did not differ essentially in succesive experimental years.

Table 4

The annual length increments of ruffe in the Odra mouth, in succesive calendar years $1 . c$. (cm)

\begin{tabular}{ccccccccccc}
\hline $\begin{array}{c}\text { Year } \\
\text { of growth }\end{array}$ & $l_{1}$ & $l_{2}-l_{1}$ & $l_{3}-l_{2}$ & $t_{4}-l_{3}$ & $l_{5}-l_{4}$ & $l_{6}-l_{5}$ & $l_{7}-l_{6}$ & $l_{8}-l_{7}$ & $l_{9}-l_{8}$ \\
\hline 1984 & 6.17 & 2.62 & 1.20 & 1.17 & 0.90 & 0.82 & 0.81 & 0.48 & 0.57 \\
\hline 1983 & 6.14 & 2.25 & 1.03 & 1.14 & 1.03 & 1.05 & 0.91 & 1.11 & \\
\hline 1982 & 6.02 & 2.89 & 1.72 & 1.19 & 0.97 & 1.09 & 1.36 & & \\
\hline 1981 & 5.68 & 2.50 & 1.51 & 1.01 & 1.32 & 0.78 & & & \\
\hline 1980 & 5.53 & 2.63 & 1.61 & 0.94 & 1.00 & & & & \\
\hline 1979 & 5.73 & 2.46 & 1.63 & 1.18 & & & & & \\
\hline 1978 & 5.62 & 2.92 & 1.14 & & & & & & \\
\hline 1977 & 5.54 & 2.29 & & & & & & & \\
\hline 1976 & 6.00 & & & & & & & & \\
\hline
\end{tabular}

Based on empirical data of the ruffe's growth rate (Table 2), parameters of von Bertalanffy's equation were estimated as well as $t_{\max }$ and $L_{\max }$ counted by the quadratic polynomials method. The parameters are as follows: 


$\begin{array}{lccccc} & \begin{array}{c}L_{\infty} \\ (\mathrm{cm})\end{array} & \mathbb{K} & \begin{array}{c}t_{o} \\ \text { (year) }\end{array} & \begin{array}{r}L_{\max } \\ (\mathrm{cm})\end{array} & \begin{array}{r}t_{\max } \\ \text { (years) }\end{array} \\ \text { Szczecin Lagoon } & 14.63 & 0.3698 & -0.23 & 14.04 & 8.34 \\ \text { Odra mouth } & 17.10 & 0.2072 & -0.97 & 15.47 & 11.42 \\ \text { Lake Dąbie } & 16.39 & 0.2317 & -0.86 & 14.66 & 9.92\end{array}$

The theoretical body lengths of the ruffe estimated for succesive years of fish life, gathered in Table 6, confirm the both models of the fish length growth rate to fit empirical data.

The annual length increments of ruffe in Lake Dąbie,

Table 5

in succesive calendar years l.c. (cm)

\begin{tabular}{ccccccccc}
\hline $\begin{array}{c}\text { Year } \\
\text { of growth }\end{array}$ & $l_{1}$ & $l_{2}-l_{1}$ & $l_{3}-l_{2}$ & $l_{4}-l_{3}$ & $l_{5}-l_{4}$ & $l_{6}-l_{5}$ & $l_{7}-l_{6}$ & $l_{8}-l_{7}$ \\
\hline 1984 & 5.90 & 2.35 & 1.49 & 1.36 & 0.93 & 0.73 & 0.85 & 0.91 \\
\hline 1983 & 5.78 & 2.86 & 1.56 & 1.16 & 0.94 & 1.00 & 0.93 & \\
\hline 1982 & 5.89 & 2.84 & 1.35 & 1.17 & 0.90 & 1.26 & & \\
\hline 1981 & 5.60 & 2.34 & 1.51 & 1.29 & 1.11 & & & $\ddots$ \\
\hline 1980 & 5.66 & 2.56 & 1.89 & 1.18 & & & & \\
\hline 1979 & 5.46 & 2.80 & 1.64 & & & & & \\
\hline 1978 & 5.81 & 2.67 & & & & & & \\
\hline 1977 & 5.13 & & & & & & &
\end{tabular}

Table 6

Comparison of the length growth of ruffe in the studied water basins estimated by the back readings method (1), by von Bertalanffy's equation (2) and by quadratic polynomial (3) - 1 . c. (cm).

\begin{tabular}{|c|c|c|c|c|c|c|c|c|c|}
\hline \multirow{2}{*}{$\begin{array}{l}\text { Age of } \\
\text { fish }\end{array}$} & \multicolumn{3}{|c|}{ Szczecin Lagoon } & \multicolumn{3}{|c|}{ Odra mouth } & \multicolumn{3}{|c|}{ Lake Dąbie } \\
\hline & 1 & 2 & 3 & 1 & 2 & 3 & 1 & 2 & 3 \\
\hline 1 & 5.82 & 5.35 & 6.22 & 5.96 & 5.74 & 6.27 & 5.79 & 5.74 & 6.19 \\
\hline 2 & 8.63 & 8.22 & 8.21 & 8.25 & 7.86 & 7.95 & 8.34 & 7.94 & 7.98 \\
\hline 3 & 10.11 & 10.20 & 9.90 & 9.79 & 9.59 & 9.46 & 9.89 & 9.69 & 9.56 \\
\hline 4 & 11.36 & 11.57 & 11.31 & 10.70 & 11.00 & 10.80 & 11.09 & 11.08 & 10.93 \\
\hline 5 & 12.32 & 12.52 & 12.42 & 11.87 & 12.14 & 11.98 & 11.76 & 12.17 & 12.08 \\
\hline 6 & 13.14 & 13.17 & 13.24 & 12.78 & 13.07 & 12.98 & 12.77 & 13.05 & 13.03 \\
\hline 7 & 13.49 & 13.62 & 13.78 & 13.70 & 13.82 & 13.81 & 13.61 & 13.74 & 13.75 \\
\hline 8 & 14.08 & 13.93 & 14.02 & 14.71 & 14.44 & 14.48 & 14.55 & 1429 & 14.27 \\
\hline 9 & 14.13 & 14.15 & 13.97 & 14.95 & 14.93 & 14.97 & - & - & - \\
\hline \multirow{2}{*}{$\begin{array}{c}\text { Average } \\
\text { difference }\end{array}$} & & (2) $-(1)$ & (3) $-(1)$ & & (2) $-(1)$ & (3) $-(1)$ & & (2) $-(1)$ & (3) $-(1)$ \\
\hline & & 0.19 & 0.20 & & 0.23 & 0.19 & & 0.22 & 0.28 \\
\hline
\end{tabular}




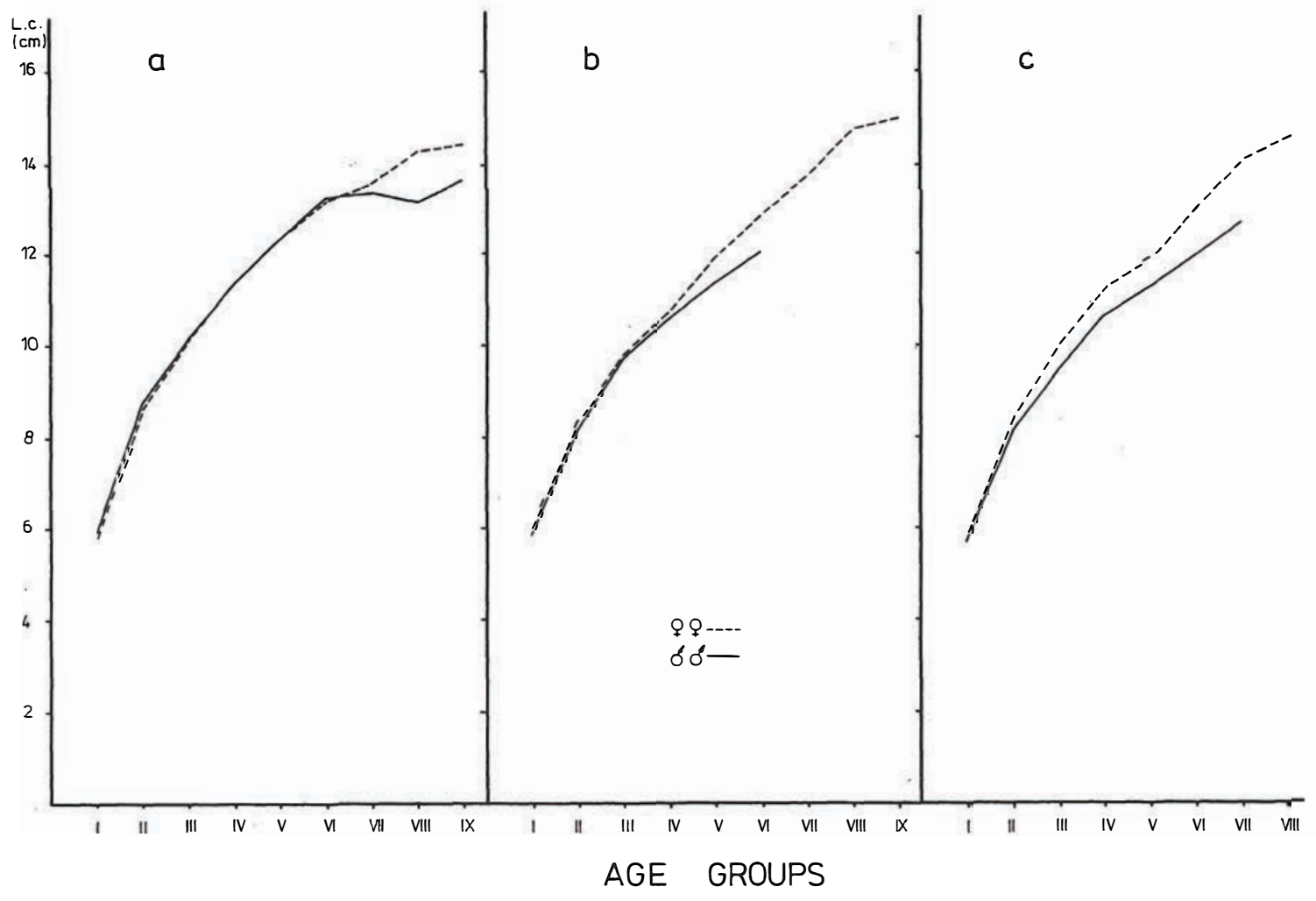

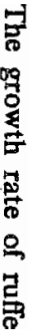

Fig. 4. Comparison of the body length growth rates of ruffe males and females in the studied water basins: a) the Szczecin Lagoon b) the Odra mouth c)Lake Dąbie 
Analysis of ruffe males and females growth rates (Table 2, Fig. 4) showed the growth rates of both sexes in the Szczecin Lagoon to be alike, with visibly higher growth rate of females in Lake Dąbie. Differences between the average body lengths of males and females stated, were statistically significant (significance level $\alpha=0.05$ ) since the third year of growth, as noted by the Student's $t$ test. For the Odra mouth the growth rates of males and females from the first four age groups are alike (Fig. 4b). A drop in the growth rate noted for older males can result from a nonrepresentative sample used (only 2 males from the $V$ and VI age groups, were examined).

\section{Weight growth rate}

Figure 5 shows the weight growth rate of the ruffe, while Figure 6 presents the ruffe's length - weight relationship in the studied water basins. Very alike in the Odra mouth and Lake Dąbie, the weight growth rate of ruffe in the Szczecin

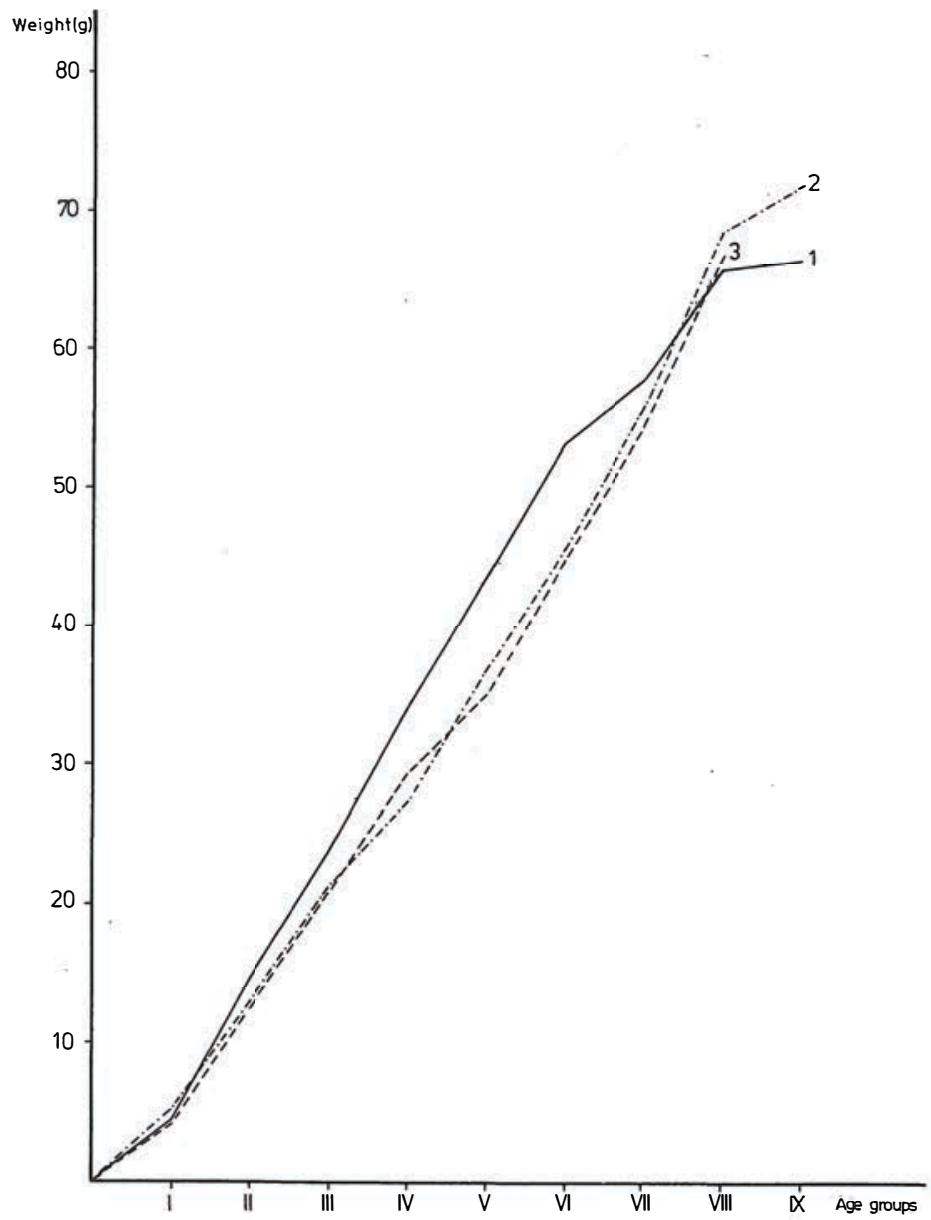

Fig. 5. Weight growth rate of rufie in the studied water basins. 1 - the Szczecin Lagoon; 2 - the Odra mouth; 3 - Lake Dąbie. 
Lagoon is slightly faster. It results iboth, from a bigger length of ruffe from the Szczecin Lagoon, in succesive years of life (up to the age of 6), and from a better condition of fish, which is shown by a more steep course of curve for the length-weight relationship (Fig. 6).

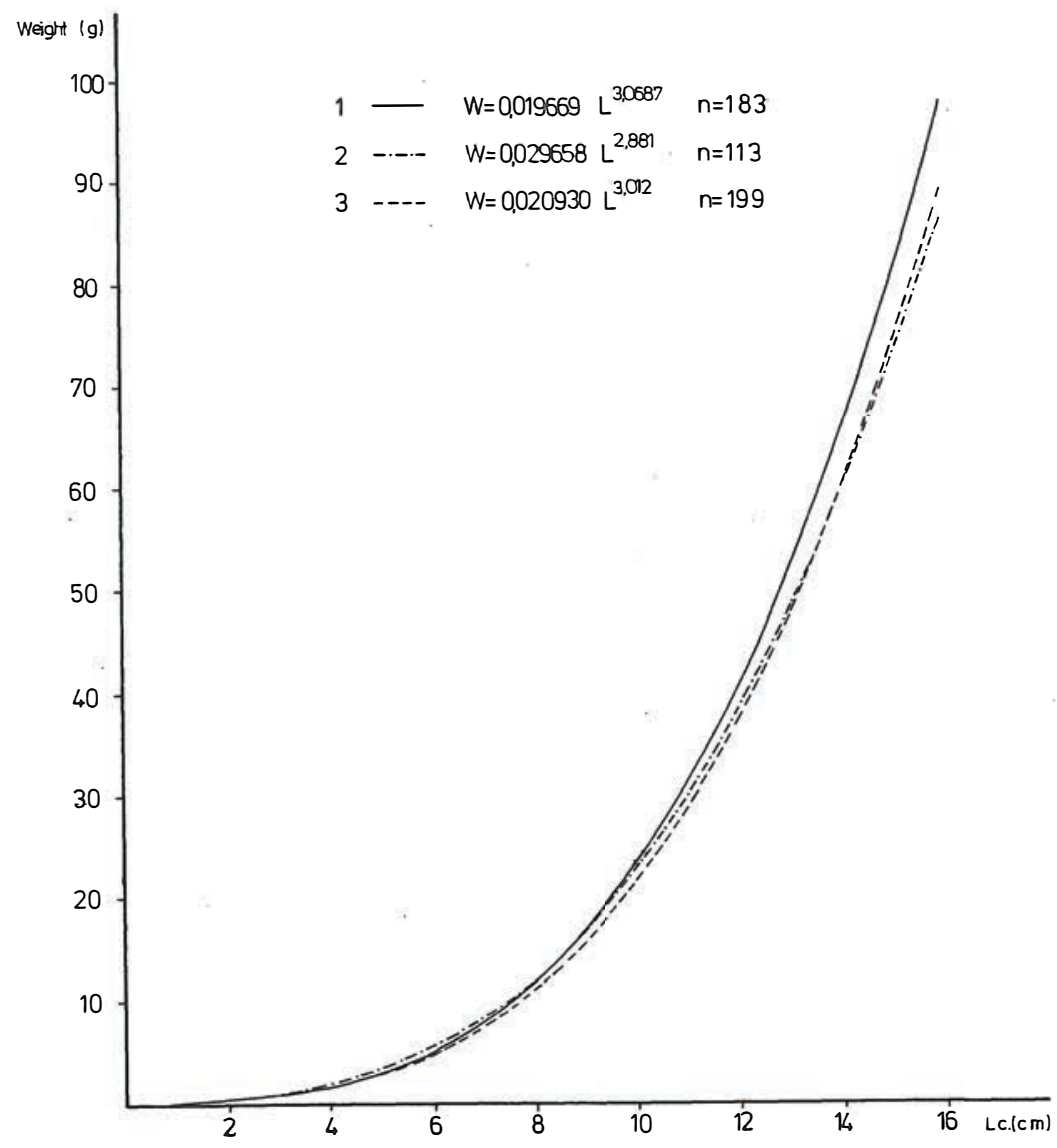

Fig. 6. Relationship between body length and body weight of ruffe in the studied water basins. 1 - the Szczecin Lagoon; 2 - the Odra mouth; 3 - Lake Dąbie.

Comparison of the average weight of ruffe, in succesive years of life, calculated from the length-weight relationship, with theoretical data, estimated by the modified von Bertalanffy's equation and cubic polynomials (Table 7) indicated a polynomial model to characterise better the ruffe's weight groth. The average differences between corresponding theoretical and experimental data, visibly lower for a theoretical weight estimated by the cubic polynomial, give evidence to that. The average weight increments, in the succesive years of life are put together in Table 7. In the first year they range from 4.2 to $5.1 \mathrm{~g}$, 
Table 7

Comparison of the body weight growth of ruffe in the studied water basins estimated by the length-weight relationship (1), by the modified von Bertalanffy's equation (2) and by cubic polynomial $(3)-(g)$

\begin{tabular}{|c|c|c|c|c|c|c|c|c|c|c|c|c|}
\hline \multirow{2}{*}{$\begin{array}{l}\text { Age of } \\
\text { fish }\end{array}$} & \multicolumn{3}{|c|}{ Szczecin Lagoon } & \multicolumn{3}{|c|}{ Odra mouth } & \multicolumn{3}{|c|}{ Lake Dąbie } & \multicolumn{3}{|c|}{$\begin{array}{l}\text { Body weight } \\
\text { increment }\end{array}$} \\
\hline & 1 & 2 & 3 & 1 & 2 & 3 & 1 & 2 & 3 & $\begin{array}{l}\text { Szcze- } \\
\text { cin } \\
\text { Lagoon }\end{array}$ & $\begin{array}{l}\text { Odra } \\
\text { mouth }\end{array}$ & $\begin{array}{l}\text { Lake } \\
\text { Dąbie }\end{array}$ \\
\hline 1 & 4.4 & 3.4 & 4.8 & 5.1 & 4.6 & 5.9 & 4.2 & 4.0 & 5.3 & 4.4 & 5.1 & 4.2 \\
\hline 2 & 14.7 & 12.6 & 14.0 & 13.0 & 11.3 & 12.1 & 12.5 & 10.8 & 11.4 & 10.3 & 7.9 & 8.3 \\
\hline 3 & 23.8 & 24.5 & 24.0 & 21.2 & 20.0 & 19.7 & 20.8 & 19.6 & 19.3 & 9.1 & 8.2 & 8.3 \\
\hline 4 & 34.1 & 36.1 & 34.1 & 27.4 & 29.7 & 28.3 & 29.4 & 29.3 & 28.4 & 10.3 & 6.2 & 8.6 \\
\hline 5 & 43.7 & 45.9 & 43.7 & 37.0 & 39.4 & 37.5 & 35.1 & 38.9 & 37.8 & 9.6 & 9.6 & 5.7 \\
\hline 6 & 53.3 & 53.7 & 52.4 & 45.7 & 48.8 & 47.0 & 44.9 & 47.9 & 46.9 & 9.6 & 8.7 & 9.8 \\
\hline 7 & 57.7 & 59.5 & 59.5 & 55.9 & 57.3 & 56.4 & 54.5 & 56.0 & 54.9 & 4.4 & 10.2 & 9.6 \\
\hline 8 & 65.8 & 63.8 & 64.6 & 68.6 & 64.9 & 65.3 & 66.6 & 63.0 & 64.2 & 8,1 & 12.7 & 12.1 \\
\hline 9 & 66.6 & 66.9 & 66.9 & 71.8 & 71.6 & 73.4 & - & - & - & 0.8 & 3.2 & - \\
\hline \multirow{2}{*}{$\begin{array}{l}\text { Average } \\
\text { difference }\end{array}$} & \multicolumn{3}{|c|}{$(2)-(1)(3)-(1)$} & \multicolumn{3}{|c|}{$(2)-(1)(3)-(1)$} & \multicolumn{3}{|c|}{$(2)-(1)(3)-(1)$} & & & \\
\hline & & 1.4 & 0.6 & & 1.8 & 1.3 & & $1: 9$ & 1.5 & & & \\
\hline
\end{tabular}

while ones between second and eighth years of life are differentiated only slightly, ranging mostly from 8 to $10 \mathrm{~g}$, with no increasing tendency, when fish grows older.

\section{DISCUSSION}

Table 8 presents results of surveys on the length growth rates of ruffe in various water basins. Not always the results are fully comparable to the ones obtained in this work, due to the differences in the applied experimental methods, however some comparison can be done. The length growth rate of ruffe from the Szczecin Lagoon studied by Kolender (1969) in 1968 was very close to the one noted in this work, in $1985-1986$, except for essential difference in the ruffe's growth rate in its first year of life. Comparison to the data of Neuhaus from 1934 (Bast et al., 1983), points out to a visible acceleration in the ruffe's growth rate during last twenty five years, when compared to the one noted in the thirties.

Comparing the growth rate of the investigated species from various water basins, one can notice the tested ruffe's populations belong to the fast growing ones. Only in the Baltic sea-side lagoons of GDR (Darss-Zingster Boddenkette and Grossen Jasmunder Bodden) the growth rate of ruffe is equally fast during the first three years of life and even faster, when aged four-five (Bast et al, 1983). In typical inland waters, including those to the west and south from Poland, that 
Comparison of the body length growth rate of ruffe in various water basins $(1 . c . / \mathrm{cm})$

Table 8

\begin{tabular}{|c|c|c|c|c|c|c|c|c|c|c|c|}
\hline \multirow{2}{*}{$\begin{array}{l}\text { Water basin } \\
\quad \text { and } \\
\text { experimental me- } \\
\text { thod applied }\end{array}$} & \multirow{2}{*}{$\begin{array}{l}\text { Sampling } \\
\text { period }\end{array}$} & \multicolumn{9}{|c|}{ Age of fish (in years) } & \multirow{2}{*}{$\begin{array}{r}\text { Source of } \\
\text { information }\end{array}$} \\
\hline & & 1 & 2 & 3 & 4 & 5 & 6 & 7 & 8 & 9 & \\
\hline $\begin{array}{l}\text { Szczecin } \\
\text { Lagoon * }\end{array}$ & $\begin{array}{c}\text { no data } \\
\text { available }\end{array}$ & 5.88 & 7.60 & 8.72 & 9.75 & - & - & - & - & - & $\begin{array}{l}\text { Bast et al., } \\
1983 \text { after } \\
\text { Neuhaus, } 1934\end{array}$ \\
\hline $\begin{array}{l}\text { Szczecin Lagoon, } \\
\text { back readings }\end{array}$ & 1968 & 7.26 & 8.75 & 10.09 & 11.36 & 12.11 & 13.41 & - & - & - & Kolender, 1969 \\
\hline $\begin{array}{l}\text { Szczecin Lagoon, } \\
\text { back readings }\end{array}$ & $\begin{array}{l}1985- \\
1986\end{array}$ & 5.82 & 8.63 & 10.11 & 11.36 & 12.32 & 13.14 & 13.49 & 14.08 & 14.13 & $\begin{array}{l}\text { present } \\
\text { surveys }\end{array}$ \\
\hline $\begin{array}{l}\text { Lake Dąbie, } \\
\text { back readings }\end{array}$ & $\begin{array}{l}1985- \\
1986\end{array}$ & 5.79 & 8.34 & 9.89 & 11.09 & 11.76 & 12.77 & 13.61 & 14.55 & - & $\begin{array}{l}\text { present } \\
\text { surveys }\end{array}$ \\
\hline $\begin{array}{l}\text { Small Lagoon } \\
\text { (GDR)*, direct } \\
\text { measurements }\end{array}$ & $\begin{array}{l}1979- \\
1980\end{array}$ & - & 7.95 & 9.24 & 10.96 & 13.54 & - & - & - & - & $\begin{array}{l}\text { Bast et al.; } \\
1983\end{array}$ \\
\hline $\begin{array}{l}\text { Darss-Zingster } \\
\text { Boddenkette } \\
\text { (GDR)*, back } \\
\text { readings }\end{array}$ & $\begin{array}{l}1979- \\
1980\end{array}$ & 6.49 & 7.92 & 9.24 & 11.30 & 14.14 & 15.60 & - & - & - & $\begin{array}{l}\text { Bast et al., } \\
1983\end{array}$ \\
\hline $\begin{array}{l}\text { Grossen Jasmun- } \\
\text { der Bodden } \\
\text { (Rugia)*, direct } \\
\text { measurements }\end{array}$ & $\begin{array}{l}1979- \\
1980\end{array}$ & - & - & 10.49 & 12.63 & 14.77 & 15.37 & - & - & - & $\begin{array}{l}\text { Bast et al., } \\
1983\end{array}$ \\
\hline $\begin{array}{l}\text { Kurskiy Lagoon, } \\
\text { direct } \\
\text { measurements }\end{array}$ & $\begin{array}{l}1968- \\
1977\end{array}$ & 5.1 & 5.8 & 6.9 & 8.2 & 8.8 & 9.9 & - & - & - & Kozlova, 1979 \\
\hline $\begin{array}{l}\text { Lake Tajty, back } \\
\text { readings }\end{array}$ & 1951 & 3.9 & 6.6 & 8.2 & - & - & - & - & - & - & Zawisza, 1953 \\
\hline $\begin{array}{l}\text { Lake Bukowo*, } \\
\text { back readings }\end{array}$ & $\begin{array}{l}1976- \\
1977\end{array}$ & 2.70 & 4.42 & 5.80 & 6.83 & 8.89 & 10.36 & - & - & - & $\begin{array}{l}\text { Adamus et al., } \\
1978\end{array}$ \\
\hline $\begin{array}{l}\text { Lake Ilmen } \\
\text { (USSR), direct } \\
\text { measurements }\end{array}$ & 1972 & 4.46 & 5.93 & 7.35 & 8.80 & 9.70 & 10.40 & - & - & - & $\begin{array}{l}\text { Fedorova and Vet- } \\
\text { kasov, } 197.4\end{array}$ \\
\hline $\begin{array}{l}\text { Lake Ijssel } \\
\text { (Holland)* }\end{array}$ & $\begin{array}{l}1966- \\
1976\end{array}$ & 4.77 & 7.35 & 8.21 & 9.07 & - & - & - & - & - & $\begin{array}{l}\text { Willemsen, } \\
1977\end{array}$ \\
\hline $\begin{array}{l}\text { average from } 23^{*} \\
\text { German } \\
\text { lakes }\end{array}$ & $\begin{array}{l}\text { no data } \\
\text { available }\end{array}$ & 4.77 & 7.35 & 9.07 & 9.93 & 11.64 & - & - & - & - & Bauch, 1963 \\
\hline $\begin{array}{l}\text { ponds } \\
\text { (Czechoslovakia), } \\
\text { back readings }\end{array}$ & $\begin{array}{l}\text { no data } \\
\text { available }\end{array}$ & 5.4 & 7.6 & 8.9 & 10.2 & 10.5 & 11.3 & 11.9 & - & - & Johal, 1980 \\
\hline
\end{tabular}

* - a body length (1.c.) recalculated from a total body length (1.t.). 
Comparison of the weight growth of ruffe in various water basins (g)

\begin{tabular}{|c|c|c|c|c|c|c|c|c|c|c|c|}
\hline \multirow{2}{*}{ Water basin } & \multirow{2}{*}{$\begin{array}{l}\text { Sampling } \\
\text { period }\end{array}$} & \multicolumn{9}{|c|}{ Age of fish (in years) } & \multirow{2}{*}{$\begin{array}{c}\text { Source of } \\
\text { information }\end{array}$} \\
\hline & & 1. & 2 & 3 & 4 & 5 & 6 & 7 & 8 & 9 & \\
\hline Szczecin Lagoon & 1968 & 9.1 & 14.8 & 22.3 & 31.6 & 42.6 & 49.0 & - & - & - & Kolender, 1969 \\
\hline Szczecin Lagoon & $\begin{array}{r}1985- \\
1986\end{array}$ & 4.4 & 14.7 & 23.8 & 34.1 & 43.7 & 53.3 & 57.7 & 65.8 & 66.6 & present surveys \\
\hline Lake Dąbie & $\begin{array}{c}1985- \\
1986\end{array}$ & 4.2 & 12.5 & 20.8 & 29.4 & 35.1 & 44.9 & 54.5 & 66.6 & - & present surveys \\
\hline Small Lagoon (GDR) & $\begin{array}{r}1979- \\
1980\end{array}$ & - & 10.3 & 18.4 & 31.7 & - & - & - & - & - & Bast et al., 1983 \\
\hline $\begin{array}{l}\text { Darss-Zingster } \\
\text { Boddenkette (GDR) }\end{array}$ & $\begin{array}{r}1979- \\
1980\end{array}$ & 6.3 & 11.1 & 18.4 & 33.8 & 66.3 & 93.5 & - & - & - & Bast et al., 1983 \\
\hline $\begin{array}{l}\text { Grossen Jasmunder } \\
\text { Bodden (Rugia) }\end{array}$ & $\begin{array}{r}1979- \\
1980\end{array}$ & - & - & - & 59.2 & 80.4 & 89.9 & - & - & - & Bast et al., 1983 \\
\hline Kurskiy Lagoon & $\begin{array}{c}1968- \\
1977\end{array}$ & 2.7 & 4.8 & 7.6 & 10.3 & 13.9 & 18.9 & - & - & - & Kozlova, 1979 \\
\hline Lake Bukowo & $\begin{array}{r}1976- \\
1977\end{array}$ & 1.2 & 3.3 & 5.8 & 9.6 & 15.6 & 21.7 & - & - & - & $\begin{array}{l}\text { Adamus et al., } \\
1978\end{array}$ \\
\hline Lake Ilmen & 1972 & 3.0 & 7.9 & 12.3 & 15.9 & 20.7 & 24.5 & - & - & - & $\begin{array}{l}\text { Fedorova and Vet- } \\
\text { kasov, } 1974\end{array}$ \\
\hline Lake Tajty & 1951 & 1.6 & 5.9 & 10.0 & - & - & - & - & - & - & Zawisza, 1953 \\
\hline
\end{tabular}


is, with the higher average temparatures, the ruffe's growth is slower from the one noted for the Szczecin Lagoon. Salinity of deecer parts of the Szczecin Lagoon exceeds periodically $7 \%$, after marine water inflow (Najewski, 1980), reaching typical level for brackish waters. It produces better conditions for rufie and enables its higher, than an average, growih rate. Sivdying the growin rate of pikeperch, perch and ruffe ifir the waters of Findand. Lind (1977, noted the average growth rate of all three species to be faster in brackish than in fresh waters. According to $\mathbb{L}$ ind the brackish waters contain more food available than the fresh ones. Also surveys, conducted in $\mathbb{L}$ ake $\mathbb{L}$ auwersmeer in Folland (Villemsen, 1977), indicated an exceptional, for the European conditions, growth rate of ruffe (15 cm 1.t. after the second year of Hife). According to Willemsen, three years prior to the surveys, the above mentioned Lake was a marine bay, that was where an abundant food resources came from.

Among the populations of ruffe under comparison (Table 9), the fastest weight growth was noted for population from the Szczecin Lagoon (during first three years of life) and previously mentioned ones from the lagoons in GDR (from fourth to sixth years of life). The body weight growth was particularly sllow for ruffe from Lake Bukowo (Adamus et al.s 1978).

A particular uniformity in the body weight growth of ruffe has been confirmed by Szypula (1977). Among the 36 species uncer investigation, ruffe had the most uniform growth in body length and body weight, in particular. An average weight growth rate of ruffe, equal to $7 \mathrm{~g} / y e a r$, approached that, estimated in the present surveys (Table 7), for ruffe aged 2 to 8 , as an annual average. Such a uniformity in the body weight growth has not been typicall for other Percidae representatives in water basins, in Poland. The body weight increments of perch during the eighth year of growth, for example, can be 4.3 to 19 times higher than the one noted for the second year of growth (Zuromska, 1961). Also pikeperch's bodly weight increments for the fourth or fifth year of growth can exceed 4 times that for the second one (Nagieć, 1961).

Variability in the growth rate of ruffe due to sex of fish was stated by various authors (Berg, 1949; Fedorova and Vetkasov, 1974; $\mathbb{K}$ olomin, 1977 and Bast et all, 1983). In all the works cited growth rate of females was faster, despite various age range of the fish tested. Therefore, faster growth of ruffe females from $\mathbb{L}$ ake $\mathbb{D} a ̨ b i e(F i g .4 c)$ can be treated as typical, while the uniform growth rates of ruffe males and females from the Szczecin Lagoon (Fig. 4a) and possibly from the Odra mouth (Fig. 4b) can be treated rather, as exceptional. 


\section{REFERENCES}

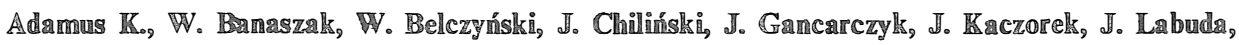

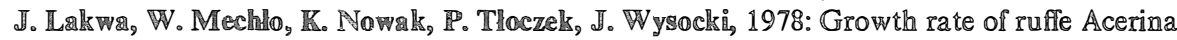
cernua (L., 1758) in Lake Bukowo. - $\mathbb{Z}$-ty Studenckiego $\mathbb{R} u c h u$ Naukowego $\mathbb{A}$ Szczecin, 1: 189-201.

Bast $H_{0}, M_{\text {. Winlkler, }}$ W. Hahm, 1983: Bemerkungen zur Biologie und Bedeutung des Kaulbarsches (Gymnocephalus cermua) der Darss - Zingster Boddenkette. - Fisch. - Forsch., 21 (4): $34-38$.

Banch $\mathbb{G}_{\circ}$, 1963: Die einheimischen Süsswasserfische. - Neumann Verlag, Radebeul - Berlin.

Berg L. So, 1949: Ryby presnych vod SSSR i sopredelnych stran. - Izd. Akad. Nauk SSSR, Moskwa - Leningrad. (in Russian).

Collete B. Ba, $\mathbb{P}$. Bammrescin, 1977: Systematics and zoogeography of the fishes of the family Percidae. - J. Fish. Res. Board Can., 34 (10): 1450-1463.

Fedorova G. $\mathbb{V}_{\circ}$ S. A. Vettrasov, 1974: Biologičeslkaja charalkteristika i čislennost erša Acerina cernua (L.) ozera Ilmen. - Vopr. Ichtiol., 14 (6): 968 - 973. (in Russian).

Gąsowsks $\mathbb{M}_{\text {of }}$ (ed.), 1962: Keys to identification of vertebrates in Poland. Part I. The Cyclostomata and the Pisces, Cyclostomi et Pisces. - PWN, Warsaw (in Pollish).

Johnl M. So, 1980: Growth of ruffe, Acerina cemua (Pisces, Perciformes) in Czechoslovakia - Vest. čs Společ. zool., 44: $183-196$.

Kolender $\mathbb{E}_{\text {no }}$ 1969: Age and growth rate of ruffe, Acerina cernua (L.) in the Szczecin $\mathbb{L} a g o o n$. - A diploma work - manuscript, Ichthyology Department, Academy of Agriculture, Szczecin.

Kolomin J. Mo, 1977: Erš Acerima cernua (L). r. Nadym. - Vopr. Ichtiol, 17 (3): 395 - 399 (in Russian).

Kozlovæ M. Fo, 1979: Čislennost erša v $1968-1977$ gg. i obosnovanije ego vylova v Kuršskom Zalivie. - Trudy AtlantNIRO, 81: 94-102. (in Russian).

Leszczyńslzi $\mathbb{L}$, 1963: Characteristic of ruffe's (Acerina cernua $\mathbb{L}$.) feed in Kortowslie Lake. - Rocz. Nauk $\mathbb{R o l}, 82-\mathbb{B}-2: 251-271$.

Limd E. A。, 1977: A review of pilkeperch (Stizostedion-lucioperca), eurasian perch (Perca fluviatilis) and ruffe (Gymnocephalus cermua) in Finnland.- J. Fish. Res. Board Can, 34 (10): 1684-1695.

IMajewsilsi Aa, (ed), 1980: The Szczecin Lagoon - Communication Publishers, Warsaw.

Nagiee Mo, 1961: Growth of pilseperch (Lucioperca lucioperca Lu) in lakes of Northern Poland.Rocz. Nauk. Rol., $77-\mathbb{B}-2.549-580$.

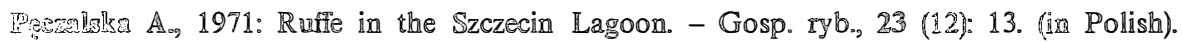

Storparia $\mathbb{I}_{0}$ 1977: Ar appliance of quadratic and cubic polynomials for the fish growth characteristic. - Academy of Agriculture, Szczecin, Thesis, no 52.

Terlecki $J_{0}$ 1983: Characteristic of meristic and biometric features of rufie (Gymnocephalus cemuus L.) from Nidzkie Lake. - Rocz. Nauk $\mathbb{R o l}, \mathbb{1} 00-\mathbb{H}-1: 179-196$.

Wyillemsem $\mathbb{J}_{\circ}$ 1977: Population dynamics of percids in Ijssel and some smaler lakes in the Netherlands. - J. Fish. Res. Board Can., 34 (10): 1710-1719.

Zawisza Jo, 1953: Growth of fishes in Lake Tajty. - Rocz. Nauk $\mathbb{R o l}, 67$ - D: $221-255$.

Zuromska $\mathbb{H}_{\circ}$, 1961: Growth of perch (Perca fluviatilis $\mathbb{L}$.) in lakes of the Wegorzewo district. - Rocz. Nauk Rol., 77 - $\mathbb{B}$ - 2: 603 - 639. 
Zbigniew Neja

\section{WZROST JAZGARZA, GYMNOCEPHALUS CERNUUS (L., 1758) W ZALEWIE SZCZECIŃSKIM, ROZTOCE ODRZAŃSKIEI I JEZIORZE DABIE}

\section{STRESZCZENIE}

W latach 1985 - 1986 przeprowadzono badania nad wzrostem jazgarza z Zalewu Szczecińskiego, Roztoki Odrzańskiej i jeziora Dąbie (tab. 1). Ustalono, że zależność między dlugością ciała (1.c.) a dhugością całkowitą (l.t.) wyraża się równaniem: 1.c. $=0,8596$ 1.t. $-0,3904$.

Szybkość wzrostu oszacowano przy pomocy odczytów wstecznych z otolitów (rys. 1) metodą Dahl-Lea. Ryby z jez. Dąbie i Roztoki Odrzańskiej charakteryzują się prawie identyczną szybkością wzrostu dhugości, natomiast z Zalewu Szczecińskiego rosną szybciej (tab. 2, rys. 3). Najszybszy wzrost notowano w pierwszym roku życia $(5,8-6,0 \mathrm{~cm})$, a następnie przyrosty diugości szyblko zmniejszają się (tab. 2, rys. 3).

W roku 1983 w Zalewie Szczecińskim jazgarze uzyskały wyższe roczne przyrosty długości niż w latach sąsiednich, podczas gdy w Roztoce Odrzańskiej i w jez. Dąbie przyrosty te były do siebie zbliżone w różnych latach kalendarzowych (tab. 3,4 i 5).

Parametry równania von Bertalanffy'ego i obliczone na podstawie wielomianu 2-go stopnia $L_{\max }$ i $t_{\max }$ wynoszą:

Zalew Szczeciński $\quad L_{\infty}=14,63 \mathrm{~cm} ; \mathbb{K}=0,3698 ; t_{o}=-0,23$ roku;

$\mathbb{L}_{\max }=14,04 \mathrm{~cm} ; t_{\max }=8,34$ lat

Roztoka Odrzańska $\quad L_{\infty}=17,10 \mathrm{~cm} ; K=0,2072 ; t_{o}=-0,97$ roku;

$L_{\max }=15,47 \mathrm{~cm} ; t_{\max }=11,42$ lat

Jezioro Dąbie $\quad L_{\infty}=16,39 \mathrm{~cm} ; K=0,2317 ; t_{o}=-0,86$ roku;

$\mathbb{L}_{\max }=14,66 \mathrm{~cm} ; t_{\max }=9,92$ lat

Obydwa modele wzrostowe są dobrze dopasowane do danych empirycznych (tab 6).

W jez. Dąbie samice rosną szybciej, zaś w pozostałych zbiornikach nie stwiedzono różnic w szyblości wzrostu w zależności od płci (tab. 2, rys. 4).

Masa jazgarzy wzrastała najszybciej w Zalewie Szczecińskim (rys. 5); wielomian 3-go stopnia lepiej niż zmodyfikowane równanie von Bertalanffy'ego charakteryzuje wzrost masy (tab. 7). W okresie od drugiego do ósmego roku życia jazgarze cechują się dużą równomiernością wrostu masy (tab. 7).

Author's address:

Received: 87.11.25

Dr. Żbigniew Neja

Instytut Oceanografii Rybackiej

i Ochrony Moŕza

Akademia Rolnicza

ul. K. Królewicza 4

71 - 550 Szczecin

Polska (Poland) 